\title{
Anechoic crescent sign
}

\author{
Ryohei Ono 주, Takatsugu Kajiyama, Yoshio Kobayashi
}

Department of Cardiovascular Medicine, Chiba University Graduate School of Medicine, Chiba, Japan

\section{Correspondence to} Dr Ryohei Ono; ryohei_ono_0820@yahoo.co.jp

Accepted 13 January 2021

\section{DESCRIPTION}

An 88-year-old Japanese man with a history of hypertension, dyslipidaemia, chronic heart failure and an old myocardial infarction after coronary artery bypass surgery 9 years ago was referred to our hospital to assess cardiac function. Although he had no abdominal symptoms, physical examination revealed a pulsatile abdominal mass (video 1). An echocardiogram showed reduced left ventricular ejection fraction, and an abdominal ultrasound revealed a bulky abdominal aortic aneurysm $(77 \mathrm{~mm} \times 64 \mathrm{~mm})$ with an echogenic mural thrombus and an anechoic crescent (AC) sign (figure $1 \mathrm{~A}$ ). Abdominal contrast $\mathrm{CT}$ revealed an abdominal aortic aneurysm with an eccentric vascular lumen and a mural thrombus containing a peripheral crescent lower density area (figure 1B). Endovascular aortic repair or surgical operation for the aneurysm was not indicated due to the anatomical structure and cardiac function; thus, antihypertensive and anticholesteremic treatments were intensified.

The AC sign in ultrasonography is a crescentshaped anechoic area between the mural thrombus and abdominal aortic aneurysmal wall, and this sign can be seen in patients with an aortic aneurysm if the mural thrombus causes complicated hemolysis in the portion contacting the aortic wall. The AC sign is correlated to the pathological finding of serosanguinous areas of thrombus liquefaction. ${ }^{1}$ Although contrast-enhanced CT allows for a detailed depiction of intraluminal thrombus morphology, it cannot evaluate the mobility of thrombus or pathological findings. The main advantages of ultrasound include speed, real-time scanning, evaluation of dynamic or pathological findings, the use on bedside or in emergency room, low cost, widespread availability and lack of patient exposure to ionising radiation. ${ }^{2}$ Ultrasonography allows for detailed and non-invasive observation, and the AC sign of ultrasonography is one of the key findings of aortic aneurysms. ${ }^{13}$

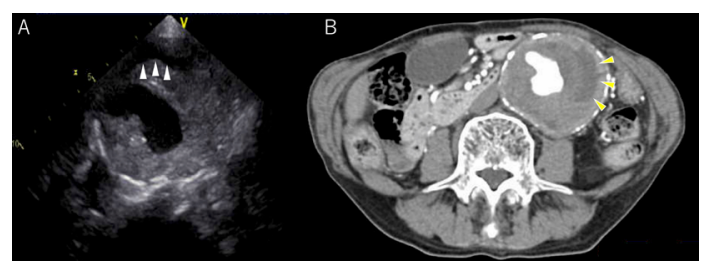

Figure 1 (A) an abdominal ultrasound showing a bulky abdominal aortic aneurysm $(77 \mathrm{~mm} \times 64 \mathrm{~mm})$ with an echogenic mural thrombus and an anechoic crescent sign (white arrows). (B) an abdominal contrast CT showing an abdominal aortic aneurysm with an eccentric vascular lumen and a mural thrombus containing a peripheral crescent lower density area (yellow arrows).

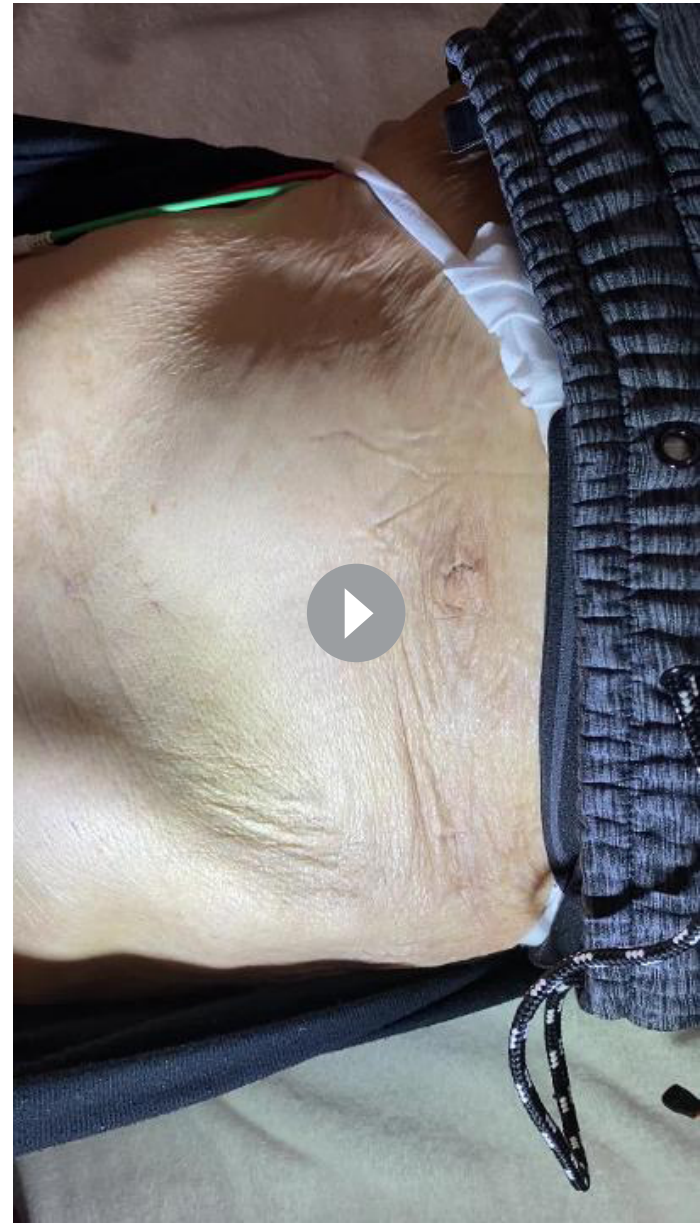

Video 1 Physical examination showing a pulsatile abdominal mass

\section{Learning points}

Anechoic crescent (AC) sign in abdominal ultrasound is associated with an aortic aneurysm.

- AC sign is a crescent-shaped anechoic area between the mural thrombus and abdominal aortic aneurysmal wall.

Contributors RO and TK contributed to the patient care and wrote the manuscript. YK contributed to critical revision of the article and approved the final version.

Funding The authors have not declared a specific grant for this research from any funding agency in the public, commercial or not-for-profit sectors.

Competing interests None declared.

Patient consent for publication Obtained.

Provenance and peer review Not commissioned; externally peer reviewed. 


\section{Images in...}

\section{ORCID iD}

Ryohei Ono http://orcid.org/0000-0002-4875-7470

\section{REFERENCES}

1 King PS, Cooperberg PL, Madigan SM. The anechoic crescent in abdominal aortic aneurysms: not a sign of dissection. AJR Am J Roentgenol 1986;146:345-8.
2 Labruto F, Blomqvist L, Swedenborg J. Imaging the intraluminal thrombus of abdominal aortic aneurysms: techniques, findings, and clinical implications. J Vasc Interv Radiol 2011;22:1069-75.

3 Nishigami K. Update on cardiovascular echo in aortic aneurysm and dissection. Ann Vasc Dis 2018;11:437-42.

Copyright 2021 BMJ Publishing Group. All rights reserved. For permission to reuse any of this content visit https://www.bmj.com/company/products-services/rights-and-licensing/permissions/

BMJ Case Report Fellows may re-use this article for personal use and teaching without any further permission.

Become a Fellow of BMJ Case Reports today and you can:

- Submit as many cases as you like

- Enjoy fast sympathetic peer review and rapid publication of accepted articles

Access all the published articles

Re-use any of the published material for personal use and teaching without further permission

\section{Customer Service}

If you have any further queries about your subscription, please contact our customer services team on +44 (0) 2071111105 or via email at support@bmj.com.

Visit casereports.bmj.com for more articles like this and to become a Fellow 